University of Nebraska - Lincoln

DigitalCommons@University of Nebraska - Lincoln

Virology Papers

Virology, Nebraska Center for

1986

\title{
HTLV-III Serology in Hemophilia: Relationship with Immunologic Abnormalities
}

Joan C. Gill

Children's Hospital of Wisconsin

Jay E. Menitove

Community Blood Center, gch@cbckc.org

Philip R. Anderson

James T. Casper

Children's Hospital of Wisconsin

Sushilkumar G. Devare

See next page for additional authors

Follow this and additional works at: https://digitalcommons.unl.edu/virologypub

Part of the Virology Commons

Gill, Joan C.; Menitove, Jay E.; Anderson, Philip R.; Casper, James T.; Devare, Sushilkumar G.; Wood, Charles; Adair, Stuart; Casey, James; Scheffel, Christi; and Montgomery, Robert R., "HTLV-III Serology in Hemophilia: Relationship with Immunologic Abnormalities" (1986). Virology Papers. 175.

https://digitalcommons.unl.edu/virologypub/175

This Article is brought to you for free and open access by the Virology, Nebraska Center for at DigitalCommons@University of Nebraska - Lincoln. It has been accepted for inclusion in Virology Papers by an authorized administrator of DigitalCommons@University of Nebraska - Lincoln. 


\section{Authors}

Joan C. Gill, Jay E. Menitove, Philip R. Anderson, James T. Casper, Sushilkumar G. Devare, Charles Wood, Stuart Adair, James Casey, Christi Scheffel, and Robert R. Montgomery 


\title{
HTLV-III Serology in Hemophilia: Relationship with Immunologic Abnormalities
}

\author{
Joan C. Gill, M.D., Jay E. Menitove, M.D., \\ Philip R. Anderson, Ph.D., James T. Casper, M.D., \\ Sushilkumar G. Devare, Ph.D., Charles Wood, Ph.D., \\ Stuart Adair, M.D., James Casey, B.S., \\ Christi Scheffel, B.S., and Robert R. Montgomery, M.D.
}

\begin{abstract}
From the Department of Pediatrics of the Medical College of Wisconsin; Blood Center of Southeastern Wisconsin; Great Lakes Hemophilia Foundation, Milwaukee; Department of Molecular Biology, Abbott Laboratories, North Chicago, Illinois

Supported in part by Grant HL 31015 of the National Heart, Lung, and Blood Institute. Submitted for publication July 24, 1985; accepted October 3, 1985.
\end{abstract}

We investigated the relationship of the presence of antibodies to HTLV-III and immunologic abnormalities in patients with hemophilia. Serum antibodies to HTLVIII were analyzed by ELISA assay, immunoprecipitation of labeled cell extracts, and immunoprecipitation of purified HTLV-III p24. Thirty-four (61\%) of the total group $(n=56)$ had antibody to HTLV-III; $34(76 \%)$ of 45 patients given commercial factor VIII preparations were seropositive, compared with none of 11 patients treated exclusively with cryoprecipitate obtained from volunteer blood donors. Of patients who were seropositive for HTLV-III antibody, $94 \%$ had abnormal T4/ T8 ratios, and 33\% of those whose serum was antibody negative had abnormal T4/T8 ratios; five patients, each antibody positive, have lymphadenopathy syndrome. Sequential studies in a subset of patients indicate that there is a changing pattern of antibody production to HTLV-III antigens after seroconversion.

Prior to reports linking human T cell lymphotropic virus type III ${ }^{1,2}$ or lymphadenopathy-associated virus ${ }^{3,4}$ with acquired immune deficiency syndrome, $\mathrm{we}^{5}$ and others ${ }^{6}$, 7 described laboratory abnormalities of immune regulation, particularly lymphocyte subset alteration, in asymptomatic patients with hemophilia. Subsequently, thrombocytopenia, lymphadenopathy syndrome, and other
AIDS-related abnormalities were noted in hemophilic patients. ${ }^{8-10}$ Furthermore, hemophilic patients given concentrates from the United States have been found to have a high prevalence of antibody to LAV/HTLV-III, ${ }^{4,11-15}$ and the appearance of antibody appears to eoincide with the AIDS epidemic. To determine whether the immunologic abnor malities are associated with evidence of infection or exposure to the retrovirus, we investigated the presence of serum antibody to one of the isolates, HTLVIII, in patients with hemophilia.

See related article, p. 504, and letter, p. 631.
AIDS Acquired immune deficiency syndrome
HTLV-III Human T cell lymphotropic virus type III
ELISA Enzyme-linked immunosorbent assay
LAV Lymphadenopathy-associated virus
SDS-PAGE Sodium dodecylsulfate-polyacrylamide gel electrophoresis

\section{METHODS}

All patients enrolled in the comprehensive care program of the Great Lakes Hemophilia Foundation who live within a 60-mile radius of Milwaukee were contacted to participate in the study; 43 patients were selected on 
Table 1. HTLV-III antibody in hemophilia

\begin{tabular}{|c|c|c|c|c|}
\hline \multirow[b]{2}{*}{ Treatment } & \multirow[b]{2}{*}{ Type } & \multirow[b]{2}{*}{$n$} & \multicolumn{2}{|c|}{ Posiłive } \\
\hline & & & $n$ & $\%$ \\
\hline \multicolumn{5}{|l|}{ Concentrate } \\
\hline \multirow[t]{3}{*}{ Factor VIII } & A severe & 32 & 27 & 84 \\
\hline & A moderate & 3 & 2 & 67 \\
\hline & A mild & 4 & 2 & 50 \\
\hline Factor VIII IX & A inhibitor & 4 & 3 & 75 \\
\hline \multirow[t]{2}{*}{ Factor IX } & B severe & 1 & 0 & 0 \\
\hline & $B$ moderate & 1 & 0 & 0 \\
\hline Total & & 45 & $\overline{34}$ & 76 \\
\hline \multirow[t]{2}{*}{ Cryoprecipitate } & A severe & 10 & 0 & 0 \\
\hline & A moderate & 1 & $\underline{0}$ & 0 \\
\hline Total & & $\overline{11}$ & $\overline{0}$ & 0 \\
\hline Total hemophilia & & 56 & 34 & 61 \\
\hline
\end{tabular}

the basis of availability to have a sample of blood taken during the 2-week period of sampling. Thirteen additional patients were selected from the Green Bay satellite center when they were evaluated for other reasons during the same period. The patients were divided into two groups, those in whom hemorrhages were treated with commercial lyophilized concentrate and those exclusively given cryoprecipitate prepared from the plasma of volunteer blood donors at the Blood Center of Southeastern Wisconsin. Histories were obtained from all patients, and all were specifically examined for the presence of lymphadenopathy and hepatosplenomegaly. Control groups included normal adults, 15 parents of hemophilic boys, five spouses of hemophilic men, and 50 homosexual men seen at a Milwaukee community medical clinic.

Clinical laboratory studies. Complete blood counts and platelet counts were performed on an ELT-8DS Blood Analyzer (Ortho Diagnostic Systems, Westwood, Mass.). White blood cell differential counts were performed by visualization of cells on a Wright-stained blood smear. Serum IgG, IgM, and IgA concentrations were determined by radial immunodiffusion (Helena Laboratories, Beaumont, Texas). Enumeration of lymphocyte subsets was determined by indirect immunofluorescence with OKT monoclonal antibodies incubated with the FicollHypaque separated mononuclear cell preparation from venous blood, as previously described. ${ }^{5}$

Virus and cells. Uninfected HT-9 cells and HT-9 cells chronically infected with HTLV-III were kindly provided by R. C. Gallo, National Cancer Institute, Bethesda, Maryland. Virus was concentrated one thousandfold, purified by density gradient centrifugation, and disrupted by sonication in the presence of $1 \%$ Triton X-100 and $0.05 \mathrm{M}$
Tris- $\mathrm{HCl}$ ( $\mathrm{pH}$ 9.0). The solution of disrupted virus was clarified by centrifugation at $100,000 \times g$ for 1 hour.

HTLV-III ELISA. In brief, the assay was performed by incubation of test sera with solubilized HTLV-III antigen bound to wells of microtiter plates or antigencoated polystyrene beads (Abbott Laboratories, North Chicago, Illinois). After washing the plates or beads, alkaline phosphatase-conjugated goat anti-human IgG was added, and after further washing the substrate $p$ nitrophenyl phosphate was used to quantitate the antibody bound.

Immunoprecipitation of labeled cell extracts. Cultures of $10^{7}$ HT -9 cells and $10^{7}$ HT-9 cells chronically infected with HTLV-III were centrifuged and washed twice in methionine- and cysteine-free medium, resuspended in $10 \mathrm{ml}$ of the same medium, and allowed to incubate at $37^{\circ} \mathrm{C}$ for 30 minutes. Cells were then collected by centrifugation and placed in $10 \mathrm{ml}$ of medium containing $100 \mu \mathrm{Ci} / \mathrm{ml}$ 35-S methionine and 100 $\mu \mathrm{Ci} / \mathrm{ml}$ 35-S cysteine. Cells were incubated for 4 hours at $37^{\circ} \mathrm{C}$ in this medium, harvested by centrifugation, and washed twice in complete media. Cells were resuspended in lysis buffer containing $10 \mathrm{mM}$ sodium phosphate, pH 7.5, $100 \mathrm{mM} \mathrm{NaCl}, 1 \%$ Triton X-100, 0.5\% sodium deoxycholate, and $0.1 \%$ sodium dodecyl sulfate at a concentration of $4 \times 10^{6}$ cells $/ \mathrm{ml}$. Ten microliters of test serum was incubated with $200 \mu \mathrm{l}$ aliquots of lysate for 30 minutes at $0^{\circ} \mathrm{C}$; Staphylococcus aureus protein A bound to Sepharose beads (Pharrnacia, Piscataway, N.J.) was then used to recover antigen-antibody complexes, which were then analyzed by SDS-PAGE as previously described. ${ }^{17}$

p-24 Radioimmunoassay. Double-antibody precipitation with ${ }^{125}$ I-labeled HTLV-III p24 was performed as previously described. ${ }^{18}$ In brief, the p24 protein was purified to homogeneity by phosphocellulose column chromatography ${ }^{18}$ and labeled with ${ }^{125} \mathrm{I}(30 \mu \mathrm{Ci} / \mu \mathrm{g})$ by Iodo-beads (Pierce Chemical Co., Rockford, Ill.). Serial dilutions of test sera were incubated with ${ }^{125}$ I-labeled purified p24, followed by precipitation of antigen-antibody complexes by incubation with anti-human IgG antisera, centrifugation to recover precipitates, and counting in an ANSA gamma counter (Abbott Laboratories). A sample was considered positive if precipitated counts were five times background.

\section{RESULTS}

Antibody to HTLV-III was detected by ELISA in 34 (61\%) of 56 hemophilic patients (Table I). Among 45 patients who received commercial lyophilized concentrate, $34(76 \%)$ had antibody to HTLV-III, compared with none of 11 patients treated exclusively with cryoprecipitate. Neither of the two patients with hemophilia B treated with factor IX concentrate had antibody, but three of four patients with inhibitors to factor VIII, all treated with 


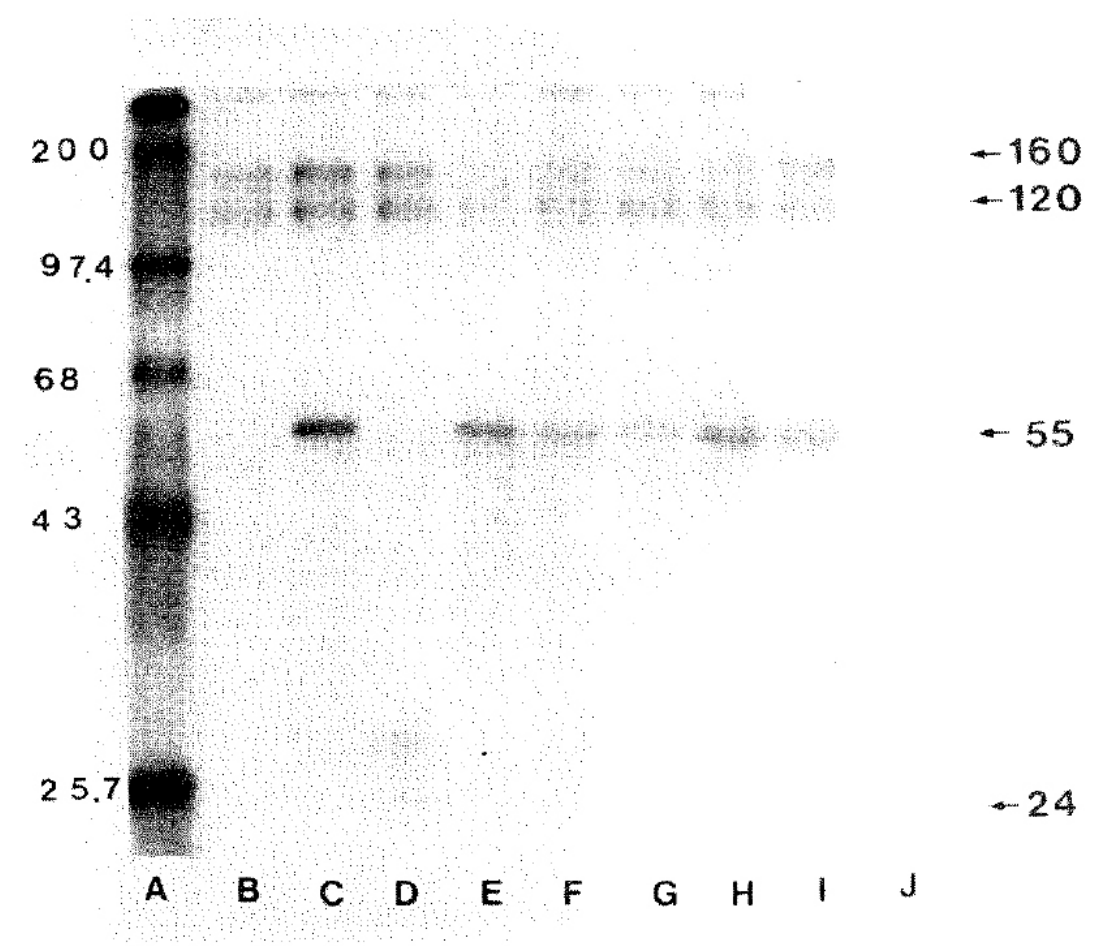

Fig. 1. Immunoprecipitation of 35-S methonine- and 35-S cysteine-labeled HTLV-III antigens by sera from patients with hemophilia. Molecular weight standards (Kd) are in lane A, with corresponding molecular weight to left of autoradiogram; molecular weights of HTLV-III antigens are shown on right. Immunoprecipitation of extract of HT-9 cells without HTLV-III is shown in lane $J$. Note variable patterns of reactivity among patients. All patient sera immunoprecipitate gp $160 / 120$. Patient $\mathrm{D}$ serum has antibody to 24 but decreased reactivity to pp55: patient B serum precipitates gp 120/160 only.

both factor VIII and factor IX concentrate, had antibody.

All patients with positive results by ELISA had antibody to viral glycoproteins gp120 and gp 160, as demonstrated by radioimmunoprecipitation of labeled cell extracts (Figure 1). Similarly, all patients who had positive ELISA results had antibodies capable of recognizing ${ }^{125} \mathrm{I}-$ labeled HTLV-III p24; however, titers of these anti-p24 antibodies varied as much as a thousandfold. Those with low antibody titers to purified p24 also lacked detection of anti-p24 by radioimmunoprecipitation of labeled cell extracts. Furthermore, the ability of these sera to precipitate pp55 varied (Figure 1). This result is not unexpected, because pp55 is a percursor protein consisting of the p24, $\mathrm{p} 17$, and $\mathrm{pl} \mathrm{S}$ gag proteins of the virus. Thus, sera with a low titer to p24 may be unable to precipitate quantities of pp55 if antibodies to other gag proteins are not present.

Chi-square analysis of immunologic status and HTLVIII serology revealed five statistically significant factors (Table II). Each of five patients with persistent generalized lymphadenopathy had HTLV-III antibody. Decreased platelet counts, decreased T4 lymphocytes, decreased T4/T8 ratios, and elevated serum IgG concentrations were associated with antibody to HTLV-III, whereas abnormal IgM and IgA and elevated T8 lym- phocytes were not associated with HTLV-III antibodies.

Sequential studies were performed on samples stored since January 1982 from 17 of the patients who were seropositive for HTLV-III; only three had results on earlier samples. In November 1982, patient 1 was seronegative for HTLV-III antibody and had a normal T4/T8 ratio. Two months later, antibody was detectable and his T4/T8 ratio decreased. Antibody and T4/T8 ratio have remained abnormal, and in May 1984, 17 months after the apperance of HTLV-III antibodies, persistent lymphadenopathy developed. Patient 2 had a similar course, with seroconversion in October 1982, a decrease in T4/ $\mathrm{T} 8$ ratio at his next evaluation, and development of generalized lymphadenopathy 22 months later. After the appearance of antibody to HTLV-III in January 1983, a third patient developed an abnormal T4/T8 ratio in November 1983, and had an episode of localized herpes zoster in February 1985.

The pattern in these three patients of serum reactivity to various HTLV-III viral proteins by immune precipitation of HTLV-III proteins is demonstrated in Figure 2. None of the initial samples precipitated viral proteins, whereas all three precipitated the gp 160-120, pp55, and p24 viral proteins when studied most recently. The patients 


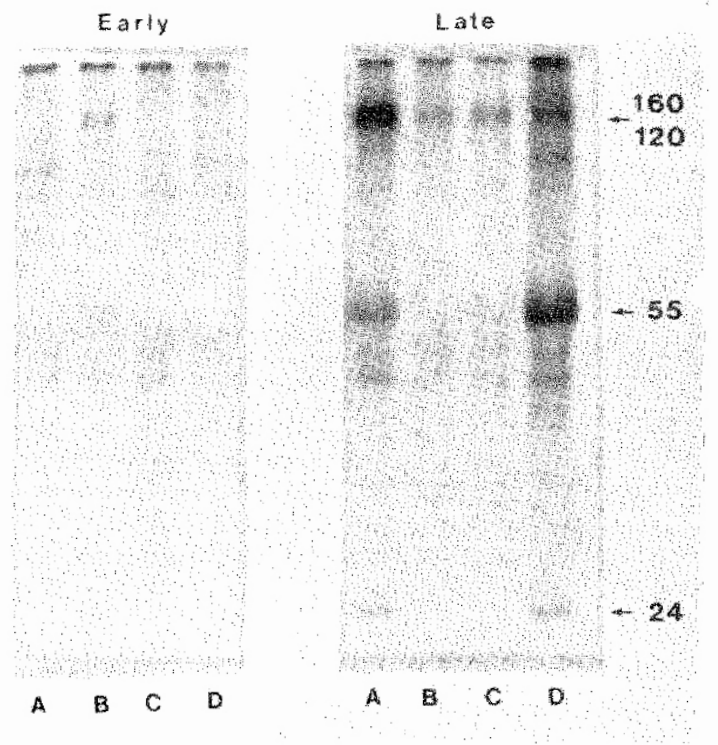

Fig. 2. Immunoprecipitation in four hemophilic patients studied sequentially. Early indicates first serum sample obtained. and late, most recent. Lantes $A, C$, and $D$ contain serum from patients 3. 1, and 2, respectively. Note absence of reactivity with viral proteins in early samples. Lane B contains serum from patient with initially positive HTI V-III ELISA in whom lymphadenopathy and thrombocytopeniz developed; note decreased reactivity with pp55 and p24 in late sample.

with lymphadenopathy precipitated relatively more pp55 and p24 than did the patient with herpes zoster. In contrast, a fourth patient, initially seropositive at the onset of the study, had an early response to p24, which was absent 18 months later; lymphadenopathy also has and more recently the onset of significant thrombocytopenia (platelet count $<50,000 / \mu 1$ ).

Selected family members were examined to some insight into the transmissibility of HTLV-III. Fifteen parents of hemophilic boys (the sons of 10 were seropositive for HTLV-III antibody) who prepared and administered treatment product were seronegative for HTLV-III antibody. Similarly, none of five spouses of hemophilic patients (two positive for HTLV-III antibody) had HTLVIII antibody. In contrast, 14 (28\%) of 50 homosexual men seen at a community medical clinic in Milwaukee were seropositive for HTLV-III by ELISA.

\section{DISCUSSION}

Evidence for a human retroviral cause for AIDS has recently accumulated. The original isolates, HTLV-III and LAV, are likely the same virus ${ }^{19}$ and have been cultured from blood, semen, and saliva from patients with AIDS or lymphadenopathy syndrome and from asymptomatic individuals from high-risk groups. ${ }^{1,3,4,11,20-27}$ Antibody to these viruses has been detected in the serum of
Toble II. Relationship of HTLV-III antibody to immunologic abnormalities in hemophilia

\begin{tabular}{|c|c|c|}
\hline & $\begin{array}{l}\text { HTLV-III } \\
\text { posifive }\end{array}$ & $\begin{array}{l}\text { HILV-III } \\
\text { negative }\end{array}$ \\
\hline \multicolumn{3}{|c|}{ Platelet count $/ \mu$ l } \\
\hline$<1,50,000$ & 5 & 0 \\
\hline \multirow[t]{2}{*}{$\geq 150,000$} & 16 & 24 \\
\hline & \multicolumn{2}{|c|}{$x^{2}=6.4 ; P<0.02$} \\
\hline \multicolumn{3}{|l|}{ T4/T8 ratio } \\
\hline$\leq 1.5$ & 30 & 8 \\
\hline \multirow[t]{2}{*}{$>15$} & 2 & 16 \\
\hline & \multicolumn{2}{|c|}{$x^{2}=22.9 ; P<0.01$} \\
\hline \multicolumn{3}{|c|}{ Total T4 iymphocytes/al } \\
\hline$<630$ & 13 & 3 \\
\hline \multirow[t]{2}{*}{$\geq 630$} & 14 & 21 \\
\hline & \multicolumn{2}{|c|}{$\chi^{2}=7.5 ; p<0.01$} \\
\hline \multicolumn{3}{|c|}{ Serum $\lg G(\mathrm{mg} / \mathrm{d}])$} \\
\hline$>1500$ & 9 & 0 \\
\hline \multirow{2}{*}{$\leq 1500$} & 13 & 18 \\
\hline & \multicolumn{2}{|c|}{$x^{2}=9.5 ; P<0.01$} \\
\hline \multicolumn{3}{|c|}{ Lymphadenopathy } \\
\hline Present & 5 & 0 \\
\hline \multirow[t]{2}{*}{ Absent } & 21 & 22 \\
\hline & \multicolumn{2}{|c|}{$x^{2}=4.7 ; P<0.05$} \\
\hline
\end{tabular}

both asymptomatic and ill individuals from these risk groups. ${ }^{1,3,4,12-16}$ Antibody to HTLV-III/LAV has been detected in $34 \%^{11}$ to $94 \%{ }^{12}$ asymptomatic hemophilic patients, a group at high risk for AIDS. In this study, $61 \%$ of hemophilic patients had evidence of prior exposure to HTLV-III/LAV. It is not known whether antibody seroconversion occurred in response to exposure to live virus and reflects or resolved infection, or resulted from exposure to inactivated virus in clotting factor replacement products. However, the presence of lymphadenopathy syndrome, thrombocytopenia, herpes zoster, and laboratory evidence of immune dysregulation similar to that associated with AIDS suggests that these patients have been exposed to live virus. Inasmuch as none of these patients has developed the full clinical symptoms of AIDS, and may have future resolution rather than progression of immunologic dysfunction, any speculation regarding the protective nature of various antibody patterns would be premature. Nevertheless, whereas only $4 \%$ of antibody-positive patients have normal T4/T8 ratios, 33\% of antibody-negative patients have abnormal T4/T8 ratios (Table II). This implies that a spectrum of in vitro laboratory abnormalities, associated with factor VIII concentrate therapy, occurs independent of HTLV-III antibody positivity. In the light of evidence suggesting that antigenemia can exist in asymptomatic antibody-negative individuals ${ }^{26}$ this interpretation is somewhat tentative pending the availability of antigen testing. 
HTLV-III/LAV appears to be transmitted by intimate sexual contact and by exposure to blood products, and not by casual contact such as typical exposure to family members other than spouses. None of the parents of hemophilic patients tested had antibody to HTLV-III. The five spouses of hemophilic patients (two antibody positive) reported had negative HTLV-III serologic findings. However, continued follow-up of this group is needed so that accurate counseling can be provided in the future; evidence for infection with HTLV-III via heterosexual transmission is now emerging. ${ }^{28-30}$

Hemophilic patients given nonheated commercial factor VIII concentrates are at high risk for development of antibody to HTLV-III and associated immunologic abnormalities. Patients given cryoprecipitate prepared from the plasma of Southeastern Wisconsin blood donors appear to be at lower risk. Preliminary evidence suggests that heat treatment of clotting factor concentrates significantly reduces retrovirus infectivity, ${ }^{31-32}$ nonheated concentrates should not be used for treatment of in patients with hemophilia.

\section{REFERENCES}

1. Popovic M, Sarngadharan MG, Read E, Gallo RC. Detection, isolation, and continuous production of cytopathic retroviruses (HTLV-III) from paricnts with AIDS and pre-AIDS. Science 1984; 224: 497-500.

2. Sarngadharan MG, Popvic M, Bruch L, Schupbach J, Gallo RC. Antibodies reactive with human T-lymphotropic retroviruses (HTLV-III) in the serum of patients with AIDS. Science 1984; 224: 506-508.

3. Barré-Sinoussi F, Chermann JC, Rey F, et al. Isolation of a lymphotropic retrovirus from a patient at risk for acquired immune deficiency syndrome (AIDS). Science 1983; 220: 868871.

4. Moniagnier L, Chermann JC, Barré-Sinoussi F, et al. A new human T-lymphotropic retrovirus: characterization and possible role in lymphadenopathy and acquired immune dcficicncv syndrome. In: Gallo RC, Essex M, Gross L, eds. T-Cell Leukemia/Lymphoma Virus 1984. Cold Spring Harbor, N.J. Cold Spring Harbor Laboratory, 1984: 363-379.

5. Menitove JE, Aster RH, Casper JT, et al. T-lymphocyte subpopulations in patients with classic hemophilia treated cryoprecipitate and lyophilized concentrates. $N$ Engl J Med 1983; 308: 83-86.

6. Lederman MM, Ratnoff OD, Scillian JJ, Jones PK, Schacter B. Impaired cell-mediated immunity in patients with classic Ikflhlphilia. N Engl J Med 1983; 308: 79-83.

7. Goldsmith JC, Moseley PL Monick M, Brady M, Hunningbake GW. T-lymphocyte subpopulation abnormalities in apparentlv healthy patients with hemophilia. Ann Intern Med 1983, 98: 294-296.

8. Ratnoff OD, Menitove JE, Aster RH, Lederman MM. Coincident classic hemophilia and "idiopathic" thrombocytopenic purpura in patients under treatment with concentrares antihemophilic factor (factor VIII). N Engl J Med 1983; 308: 439432.

9. Ragni MV, Lewis JH, Spero JA, Bontempo FA. Acquired im- munodeficiency-like syndrome in two hemophiliacs. Lancet 1983; 7: 213-214.

10. Gill JE, Menitove JE, Wheeler D, Aster RH, Montgomery RR. Generalized lymphadenopathy and T-cell abnormalities in hemophilia A. J Pediatr 1983; 103: 18-22.

11. Cheingsong-Popov R, Weiss RA, Dalgleish A, et al. Prevalence of antibody to human T-lymphotropic virus type III in AIDS and AIDS-risk patients in Britain. Lancet 1984; 2: 477480.

12. Melbye M, Froebel KS, Madhok R, et al. HTLV-III seropositivity in European haemophiliacs exposed to factor VIII concentrate imported from the USA. Lancet 1984; 2: 1,4441,446 .

13. Evatt BL, Gomperts ED, McDougal SJ, Ramsey RB. Coincidental appearance of LAV/HTLV-III antibodies in hemophiliacs and the onset of the AIDS epidemic. $N$ Engl J Med 1985; 312: 483-486.

14. Goedert JJ, Sarngadharan M, Eyster ME, et al. Antibodies reactive with human $\mathrm{T}$-cell leukemia viruses in the serum of hemophiliacs receiving factor VIII concentrate. Blood 1982; 312: 483-486.

15. Lederman MM, Ratnoff OD, Evatt BL, McDougal JS. Acquisition of antibody to lymphadenopathy-associated virus in patients with classic hemophilia (factor VIII deficiency). Ann Intern Med 1985; 102: 753-757.

16. Eyster ME, Goedert JJ, Sarngadharan MG, Weiss SH, Gallo RC, Blattner WA. Development and early natural history of HTLV-III antibodies in persons with hemophilia. JAMA 1985; 253: 2,219-2,223.

17. Laemmli UK. Cleavage of structural proteins during the assembly of the head of bacteriophage T4. Nature 1970; 227: 680-685.

18. Devare SG, Stephenson JR, Sarma PS, Aaronson SA, Chander $S$. Bovine lymphosarcoma: development of a radioimmunologic technique for detection of the immunologic agent. Science 1976; 194: 1,428-1,430.

19. Ratner L, Gallo RC, Wong-Staal F. HTLV-III, LAV, ARV are variants of same AIDS virus. Nature 1985; 313: 636-637.

20. Barré-Sinousse F, Mathur-Wagh U, Rey F, et al. Isolation of lymphadenopathy-associated virus (LAV) and detection of LAV antibodies from U.S. patients with AIDS . JAMA 1985; 253: 1,737-1,739.

21. Vilmer F, Barré-Sinoussi F, Rouzioux C, et al. Isolation of new lvmphotropic retrovirus from two siblings with haemophilia B, one with AIDS. Lancet 1984; 1: 753-757.

22. Gallo RC, Salahuddin SZ, Popovic M, et al. Frequent detection and isolation of cytopathic retroviruses (HTLV-III) from patients with AIDS and at risk for AIDS. Science 1984; 224: 500-503.

23. Feorino PM, Kalyanaraman VS, Haverkas HW, et al. Lymphadenopathy-associated virus infection of a blood donor recipient pair with acquired imrnunofcficiency syndrome. Science 1984; 225: 69-72.

24. Zagury D, Bernard J, Leibowitch J, et al. HTLV-III in saliva of people with AIDS-related complex and healthy homosexual men at risk for AIDS. Science 1984; 226: 447-451.

25. Ho DD, Schooley RT, Rata TR, et al. HTLV-III in the semen and blood of a healthy homosexual man. Science 1984; 226: 451-453.

26. Salahuddin SZ, Groopman JE, Markham PD, et al. HTLV-III in symptom-free seronegative persons. Lancet 1984; 2: 1,4181,420 . 
27. Gomperts ED, Feorino P, Evatt BL, et al. LAV/HTLV-III presence in peripheral blood lymphocytes of seropositive young hemophiliacs. Blood 1985; 65: 1,549-1,552.

28. Pitchenik AE, Shafron RD, Glasser RM, Spira TJ. The acquired immunodeficiency syndrome in the wife of a hemophiliac. Ann Intern Med 1984; 100: 62-65.

29. Redfield RR, Markham PD, Salahuddin SZ. Frequent transmission of HTLV-III among spouses of patients with AIDSrelated complex and AIDS. JAMA 1985; 253: 1,571-1,573.

30. Kreiss JK, Kitchen LW, Prince HE, Kasper CK, Essex M. An tibody to human T-lymphotropic virus type III in wives of hemophiliacs: evidence for heterosexual transmission. Ann Intern Med 1985; 102: 623-626.

31. Levy JA, Mitra G, Mozen MM. Recovery and inactivation of infectious retrovirus from factor VIII concentrates. Lancet 1984, 1: 722-723.

32. Spire B, Dormont D, Barré-Sinoussi F, Montagnier L, Chermann JC. Inactivation of lymphadenopathy-associated virus by heat, gamma rays, and ultraviolet light. Lancet 1984; 1: 188-189. 